\title{
Asthma Among Employed Adults, by Industry and Occupation — 21 States, 2013
}

\author{
Katelynn E. Dodd, $\mathrm{MPH}^{1,2}$; Jacek M. Mazurek, $\mathrm{MD}^{1}$
}

Workers in various industries and occupations are at risk for work-related asthma* (1). Data from the 2006-2007 adult Behavioral Risk Factor Surveillance System (BRFSS) Asthma Call-back Survey (ACBS), an in-depth asthma survey conducted with respondents who report an asthma diagnosis, from 33 states indicated that up to $48 \%$ of adult current asthma might be related to work and could therefore potentially be prevented (2). Identification of the industries and occupations with increased prevalence of asthma might inform work-related asthma intervention and prevention efforts. To assess the industry-specific and occupation-specific proportions of adults with current asthma by state, CDC analyzed data from the 2013 BRFSS industry and occupation module, collected from 21 states for participants aged $\geq 18$ years who, at the time of the survey interview, were employed or had been out of work for $<12$ months. Among these respondents, $7.7 \%$ had current asthma; based on the Asthma Call-back Survey results, this finding means as many as 2.7 million U.S. workers might have asthma caused by or exacerbated by workplace conditions. State-specific variations in the prevalence of current asthma by industry and occupation were observed. By state, current asthma prevalence was highest among workers in the information industry (18.0\%) in Massachusetts and in health care support occupations $(21.5 \%)$ in Michigan. Analysis of BRFSS industry and occupation and optional asthma modules can be used to identify industries and occupations to assess for asthma among workers, identify workplace exposures, and guide the design and evaluation of effective work-related asthma prevention and education programs (1).

\footnotetext{
*Work-related asthma includes occupational asthma (i.e., new-onset asthma caused by factors related to work) and work-exacerbated asthma (i.e., preexisting or concurrent asthma worsened by factors related to work). http://www.cdc. gov/niosh/topics/asthma/occasthmaprevention.html.
}

BRFSS is a state-based, random-digit-dialed telephone survey of the noninstitutionalized U.S. population aged $\geq 18$ years that collects information on health risk factors, preventive health practices, and disease status. The survey includes core questions, optional modules, and state-specific questions. ${ }^{\dagger}$ During 2013, the industry and occupation module ${ }^{\S}$ was administered for the first time in 19 states. The module collected information on the industry and occupation of respondents employed in the 12 months preceding the interview for their current or most recent job. Two additional

\footnotetext{
$\dagger$ http://www.cdc.gov/brfss/annual_data/annual_2013.html.

$\$$ http://www.cdc.gov/brfss/questionnaires/index.htm.
}

\section{INSIDE}

1332 Progress with Scale-Up of HIV Viral Load Monitoring - Seven Sub-Saharan African Countries, January 2015-June 2016

1336 Vital Signs:Trends in HIV Diagnoses, Risk Behaviors, and Prevention Among Persons Who Inject Drugs United States

1343 Description of 13 Infants Born During October 2015-January 2016 With Congenital Zika Virus Infection Without Microcephaly at Birth - Brazil

1349 Notes from the Field: Large Tuberculosis Contact Investigation Involving Two Hospitals - Okaloosa County, Florida, 2014

1351 Notes from the Field: Adverse Reaction After Vaccinia Virus Vaccination — New Mexico, 2016

1353 Announcement

1354 QuickStats

Continuing Education examination available at http://www.cdc.gov/mmwr/cme/conted_info.html\#weekly.

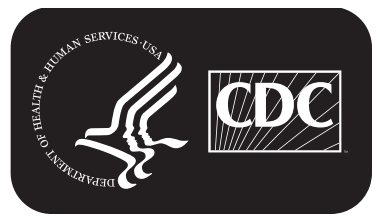

U.S. Department of Health and Human Services Centers for Disease Control and Prevention 
states (Washington and Wyoming**) collected industry and occupation information using state-added questions. The median American Association of Public Opinion Research response rate among the 21 states collecting information on industry and occupation was $44.0 \%$ (range $=31.1 \%-59.2 \%) . \dagger$

BRFSS participants who responded "yes" to both questions: "Has a doctor, nurse, or other health professional ever told you that you had asthma?" and "Do you still have asthma?" were considered to have current asthma. Participants who, at the time of the interview, indicated that they were employed for wages, out of work for $<1$ year, or self-employed were considered employed in the 12 months before the interview. Information on respondent's industry of employment and occupation was coded by CDC coders based on the 2002 North American Industry Classification System and the 2000 Standard Occupational Classification System, respectively. $\$ \$$ The current analysis used 21 industry categories and 23 occupation categories.

Landline and cellular telephone household data were weighted to produce estimates representative of the state populations using the survey sample weight for each BRFSS participant. Estimated proportions with corresponding 95\%

\footnotetext{
I Washington State Department of Health, Center for Health Statistics, Behavioral Risk Factor Surveillance System.

** Wyoming Department of Health, Public Health Division, Behavioral Risk Factor Surveillance System.

$\dagger^{\dagger}$ http://www.cdc.gov/brfss/annual_data/2013/pdf/2013_dqr.pdf.

$\$ \$$ https://wwwn.cdc.gov/niosh-nioccs/.
}

confidence intervals (CIs) were calculated. Statistically significant differences in distribution were determined using the Rao-Scott chi-square test with statistical significance at $\mathrm{p} \leq 0.05$.

A sample of 208,788 adults in the 21 states, representing an estimated 125 million persons, participated in BRFSS and completed the industry and occupation module. Among these participants, 107,327 adults, representing an estimated 74 million persons (59.8\% of the estimated survey population) were employed in the 12 months before the interview during 2013. Among adults employed at any time in the 12 months preceding the interview, $7.7 \%$ had current asthma.

The proportion of workers with current asthma differed significantly by age, sex, race/ethnicity, household income, and state (Table 1). Overall, prevalence of current asthma among workers ranged from $5.0 \%$ in Mississippi to $10.0 \%$ in Michigan, and was highest in the health care and social assistance industry $(10.7 \%)$ and in health care support occupations (12.4\%) (Table 2). Industry-specific, and occupation-specific prevalence of current asthma was highest among workers in the information industry (18.0\%) in Massachusetts and in health care support occupations (21.5\%) in Michigan (Table 3). Among the five industries with the highest current asthma prevalence, health care and social assistance was identified in 20 of the 21 states, retail trade in 16 states, and education in 14 states. Among the five occupations with the highest current asthma prevalence, office and administrative support was identified in 16 of the 21 states, health care practitioners and technical in 15 states, and sales and related in 13 states.

The MMWR series of publications is published by the Center for Surveillance, Epidemiology, and Laboratory Services, Centers for Disease Control and Prevention (CDC), U.S. Department of Health and Human Services, Atlanta, GA 30329-4027.

Suggested citation: [Author names; first three, then et al., if more than six.] [Report title]. MMWR Morb Mortal Wkly Rep 2016;65:[inclusive page numbers].

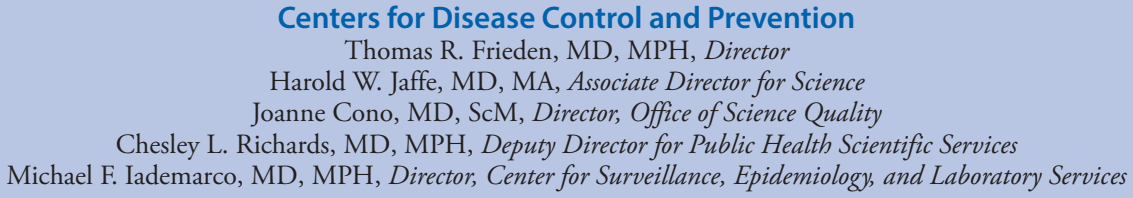

MMWR Editorial and Production Staff (Weekly)

Sonja A. Rasmussen, MD, MS, Editor-in-Chief

Charlotte K. Kent, PhD, MPH, Executive Editor Jacqueline Gindler, MD, Editor

Teresa F. Rutledge, Managing Editor

Douglas W. Weatherwax, Lead Technical Writer-Editor

Stacy A. Benton, Soumya Dunworth, PhD, Teresa M. Hood, MS, Technical Writer-Editors

Timothy F. Jones, MD, Chairman

Matthew L. Boulton, MD, MPH Virginia A. Caine, MD

Katherine Lyon Daniel, $\mathrm{PhD}$

Jonathan E. Fielding, MD, MPH, MBA

David W. Fleming, MD

MMWR Editorial Board

William E. Halperin, MD, DrPH, MPH

King K. Holmes, MD, PhD

Robin Ikeda, MD, MPH

Rima F. Khabbaz, MD

Phyllis Meadows, PhD, MSN, RN

Jewel Mullen, MD, MPH, MPA
Martha F. Boyd, Lead Visual Information Specialist

Maureen A. Leahy, Julia C. Martinroe,

Stephen R. Spriggs, Moua Yang, Tong Yang, Visual Information Specialists

Quang M. Doan, MBA, Phyllis H. King, Terraye M. Starr, Information Technology Specialists

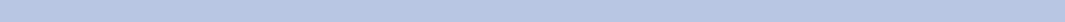


TABLE 1.Prevalence of current asthma* among adults employed during the 12 months preceding the interview, ${ }^{\dagger}$ by selected characteristics and state of residence - Behavioral Risk Factor Surveillance System (BRFSS), 21 states, 2013

\begin{tabular}{|c|c|c|c|}
\hline Characteristic/State & $\begin{array}{l}\text { No. in } \\
\text { sample }\end{array}$ & $\begin{array}{l}\text { Weighted no. } \\
\text { (thousands) }\end{array}$ & $\begin{array}{c}\text { Current asthma \%ף } \\
(95 \% \mathrm{Cl})\end{array}$ \\
\hline Total & 107,327 & 74,111 & $7.7(7.4-8.1)$ \\
\hline \multicolumn{4}{|l|}{ Age group (yrs)** } \\
\hline $18-44$ & 42,441 & 40,877 & $8.2(7.7-8.7)$ \\
\hline $45-64$ & 53,509 & 29,157 & $7.4(6.9-7.9)$ \\
\hline$\geq 65$ & 10,398 & 3,611 & $5.8(4.9-6.7)$ \\
\hline \multicolumn{4}{|l|}{$\operatorname{Sex}^{* *}$} \\
\hline Men & 50,730 & 40,516 & $5.7(5.3-6.2)$ \\
\hline Women & 56,597 & 33,595 & $10.2(9.6-10.8)$ \\
\hline \multicolumn{4}{|l|}{ Race/Ethnicity** } \\
\hline White, non-Hispanic & 83,935 & 44,493 & $8.1(7.7-8.5)$ \\
\hline Black, non-Hispanic & 7,217 & 7,478 & $8.9(7.7-10.2)$ \\
\hline Hispanic & 8,551 & 13,879 & $6.5(5.5-7.4)$ \\
\hline Other & 5,980 & 7,033 & $6.9(5.5-8.4)$ \\
\hline \multicolumn{4}{|l|}{ Education } \\
\hline $\begin{array}{l}\text { High school diploma } \\
\text { or less }\end{array}$ & 31,254 & 27,023 & $7.5(6.9-8.2)$ \\
\hline Some college & 30,274 & 22,835 & $8.2(7.5-8.8)$ \\
\hline College graduate & 45,565 & 24,089 & $7.6(7.1-8.2)$ \\
\hline \multicolumn{4}{|l|}{ Household income ${ }^{* * *}$} \\
\hline$<\$ 15,000$ & 5,302 & 5,557 & $11.4(9.5-13.3)$ \\
\hline$\$ 15,000-\$ 24,999$ & 12,154 & 9,388 & $8.0(7.1-9.0)$ \\
\hline$\$ 25,000-\$ 34,999$ & 9,558 & 6,608 & $7.5(6.3-8.7)$ \\
\hline$\$ 35,000-\$ 49,999$ & 14,212 & 9,114 & $6.9(6.1-7.7)$ \\
\hline$\geq \$ 50,000$ & 56,542 & 36,608 & $7.5(7.0-8.0)$ \\
\hline \multicolumn{4}{|l|}{ State ${ }^{* *}$} \\
\hline California & 3,966 & 16,866 & $7.6(6.6-8.6)$ \\
\hline Florida & 13,737 & 8,520 & $6.7(5.8-7.5)$ \\
\hline Illinois & 2,962 & 6,069 & $6.7(5.5-7.9)$ \\
\hline Louisiana & 2,356 & 1,998 & $6.5(4.9-8.1)$ \\
\hline Maryland & 7,126 & 2,956 & $8.6(7.5-9.7)$ \\
\hline Massachusetts & 8,238 & 3,287 & $9.9(8.9-10.9)$ \\
\hline Michigan & 6,262 & 4,279 & $10.0(9.0-11.1)$ \\
\hline Minnesota & 8,725 & 2,828 & $7.3(6.4-8.2)$ \\
\hline Mississippi & 3,190 & 1,260 & $5.0(4.0-6.0)$ \\
\hline Montana & 5,270 & 480 & $7.1(6.2-7.9)$ \\
\hline Nebraska & 4,877 & 922 & $6.3(5.2-7.3)$ \\
\hline New Hampshire & 3,582 & 666 & $8.2(7.1-9.4)$ \\
\hline New Jersey & 2,616 & 4,285 & $7.7(6.0-9.4)$ \\
\hline New Mexico & 4,661 & 885 & $8.2(7.1-9.3)$ \\
\hline New York & 2,327 & 9,162 & $7.9(6.5-9.3)$ \\
\hline North Dakota & 4,817 & 380 & $7.8(6.6-8.9)$ \\
\hline Oregon & 2,825 & 1,709 & $9.3(7.9-10.7)$ \\
\hline Utah & 7,400 & 1,322 & $8.2(7.4-9.0)$ \\
\hline Washington & 5,607 & 3,224 & $8.5(7.6-9.4)$ \\
\hline Wisconsin & 3,581 & 2,728 & $7.9(6.6-9.2)$ \\
\hline Wyoming & 3,202 & 286 & $8.3(7.0-9.6)$ \\
\hline
\end{tabular}

Abbreviation: $\mathrm{Cl}=$ confidence interval.

* "Yes" response to both questions:"Have you ever been told by a doctor or other health professional that you have asthma?" and "Do you still have asthma?"

† Participants who, at the time of the interview, indicated they were employed for wages, out of work for $<1$ year, or self-employed.

$\S$ Unweighted sample size.

" Weighted to the state population using the survey sample weights for each BRFSS participant.

** For differences in current asthma prevalence: Rao-Scott chi-square test; p-value $<0.05$.
TABLE 2. Prevalence of current asthma* among adults employed in the 12 months preceding the interview, ${ }^{\dagger}$ ranked by industry and occupation categories - Behavioral Risk Factor Surveillance System (BRFSS), 21 states, 2013

\begin{tabular}{|c|c|c|c|}
\hline Industry & $\%^{\S}(95 \% \mathrm{Cl})$ & Occupation & $\%^{\S}(95 \% \mathrm{Cl})$ \\
\hline $\begin{array}{l}\text { Health care and social } \\
\text { assistance }\end{array}$ & $10.7(9.6-11.8)$ & $\begin{array}{l}\text { Health care } \\
\text { support }\end{array}$ & $12.4(9.7-15.2)$ \\
\hline Education & $9.1(7.8-10.3)$ & $\begin{array}{l}\text { Community and } \\
\text { social services }\end{array}$ & $12.2(7.9-16.6)$ \\
\hline $\begin{array}{l}\text { Arts, entertainment, } \\
\text { and recreation }\end{array}$ & $9.0(5.1-13.0)$ & $\begin{array}{l}\text { Personal care } \\
\text { and service }\end{array}$ & $12.1(9.3-14.9)$ \\
\hline Information & $8.7(6.3-11.1)$ & $\begin{array}{l}\text { Arts, design, } \\
\text { entertainment, } \\
\text { sports, and } \\
\text { media }\end{array}$ & $11.7(8.5-14.8)$ \\
\hline Retail trade & $8.7(7.3-10.2)$ & $\begin{array}{l}\text { Office and } \\
\text { administrative } \\
\text { support }\end{array}$ & $10.2(8.7-11.7)$ \\
\hline Finance and insurance & $8.4(6.4-10.3)$ & $\begin{array}{l}\text { Health care } \\
\text { practitioners } \\
\text { and technical }\end{array}$ & $9.2(7.9-10.5)$ \\
\hline $\begin{array}{l}\text { Other services (except } \\
\text { public administration) }\end{array}$ & $8.3(6.6-9.9)$ & Legal & $9.2(5.9-12.5)$ \\
\hline $\begin{array}{l}\text { Professional, scientific, } \\
\text { and technical services }\end{array}$ & $7.6(6.1-9.1)$ & $\begin{array}{l}\text { Food preparation } \\
\text { and serving }\end{array}$ & $8.3(6.5-10.2)$ \\
\hline $\begin{array}{l}\text { Accommodation and } \\
\text { food services }\end{array}$ & $7.4(6.0-8.7)$ & $\begin{array}{l}\text { Education, } \\
\text { training, and } \\
\text { library }\end{array}$ & $8.2(6.8-9.5)$ \\
\hline $\begin{array}{l}\text { Transportation and } \\
\text { warehouse }\end{array}$ & $7.1(4.8-9.3)$ & Sales and related & $7.6(6.5-8.8)$ \\
\hline Public administration & $7.0(5.8-8.2)$ & $\begin{array}{l}\text { Life, physical, and } \\
\text { social science }\end{array}$ & $7.5(4.6-10.4)$ \\
\hline $\begin{array}{l}\text { Real estate, rental, } \\
\text { and leasing }\end{array}$ & $6.9(4.4-9.4)$ & $\begin{array}{l}\text { Business and } \\
\text { financial } \\
\text { operations }\end{array}$ & $7.2(5.6-8.9)$ \\
\hline $\begin{array}{l}\text { Administrative and } \\
\text { support, waste } \\
\text { management, and } \\
\text { remediation }\end{array}$ & $6.4(4.4-8.3)$ & $\begin{array}{l}\text { Building and } \\
\text { grounds } \\
\text { cleaning and } \\
\text { maintenance }\end{array}$ & $7.1(5.4-8.9)$ \\
\hline Manufacturing & $6.1(5.1-7.2)$ & Management & $6.9(5.7-8.0)$ \\
\hline Mining, oil and gas & $6.0(3.6-8.3)$ & $\begin{array}{l}\text { Transportation } \\
\text { and material } \\
\text { moving }\end{array}$ & $6.7(4.7-8.7)$ \\
\hline Construction & $5.9(4.5-7.2)$ & $\begin{array}{l}\text { Computer and } \\
\text { mathematical }\end{array}$ & $6.7(4.9-8.6)$ \\
\hline Wholesale trade & $5.8(3.4-8.3)$ & Protective service & $6.6(4.1-9.2)$ \\
\hline $\begin{array}{l}\text { Agriculture, forestry, } \\
\text { fishing and hunting }\end{array}$ & $4.2(2.0-6.4)$ & Production & $5.7(4.1-7.3)$ \\
\hline Utilities & & $\begin{array}{l}\text { Installation, } \\
\text { maintenance, } \\
\text { and repair }\end{array}$ & $5.7(3.9-7.5)$ \\
\hline $\begin{array}{l}\text { Management of } \\
\text { companies and } \\
\text { enterprises }\end{array}$ & - & $\begin{array}{l}\text { Construction } \\
\text { and extraction }\end{array}$ & $4.6(3.4-5.8)$ \\
\hline \multirow[t]{3}{*}{ Armed forces } & - & $\begin{array}{l}\text { Architecture and } \\
\text { engineering }\end{array}$ & $4.1(2.8-5.4)$ \\
\hline & & $\begin{array}{l}\text { Farming, fishing, } \\
\text { and forestry }\end{array}$ & $2.6(1.1-4.1)$ \\
\hline & & $\begin{array}{l}\text { Military active } \\
\text { duty }\end{array}$ & - \\
\hline
\end{tabular}

Abbreviation: $\mathrm{Cl}=$ confidence interval.

* "Yes" response to both questions: "Have you ever been told by a doctor or other health professional that you have asthma?" and "Do you still have asthma?"

† Participants who, at the time of the interview, indicated they were employed for wages, out of work for $<1$ year, or self-employed.

$\S$ Weighted to the state population using the survey sample weights for each BRFSS participant.

" Unreliable estimates with a relative standard error $\geq 30$ are not reported. 
TABLE 3. The five industries and occupations with the highest prevalence of current asthma* among adults employed in the 12 months preceding the interview, ${ }^{\dagger}$ by state - Behavioral Risk Factor Surveillance System (BRFSS), 21 states, 2013

\begin{tabular}{|c|c|c|c|}
\hline State/Industry & $\%^{\S}(95 \% \mathrm{Cl})$ & Occupation & $\%^{\S}(95 \% \mathrm{Cl})$ \\
\hline \multicolumn{4}{|l|}{ California } \\
\hline Education & $11.4(7.0-15.8)$ & Personal care and service & $16.0(7.4-24.6)$ \\
\hline Health care and social assistance & $10.9(6.8-15.1)$ & Office and administrative support & $13.0(7.9-18.2)$ \\
\hline Professional, scientific, and technical services & $9.5(5.0-13.9)$ & Education, training, and library & $8.6(4.5-12.6)$ \\
\hline Construction & $7.8(4.3-11.4)$ & Management & $7.5(4.0-11.1)$ \\
\hline Retail trade & $7.6(3.7-11.5)$ & Sales and related & $7.1(3.8-10.4)$ \\
\hline \multicolumn{4}{|l|}{ Florida } \\
\hline Retail trade & $10.0(5.6-14.4)$ & Health care practitioners and technical & $13.4(8.1-18.6)$ \\
\hline Education & $9.2(5.2-13.1)$ & Education, training, and library & $7.0(3.1-10.9)$ \\
\hline Health care and social assistance & $9.1(7.0-11.2)$ & Office and administrative support & $6.9(4.5-9.3)$ \\
\hline Other services (except public administration) & $8.3(3.9-12.6)$ & Sales and related & $6.9(4.2-9.6)$ \\
\hline Finance and insurance & $4.2(2.0-6.5)$ & Management & $4.1(2.3-5.9)$ \\
\hline \multicolumn{4}{|l|}{ Illinois } \\
\hline Health care and social assistance & $10.9(6.7-15.2)$ & Health care practitioners and technical & $14.7(7.9-21.4)$ \\
\hline Retail trade & $10.2(4.3-16.0)$ & Office and administrative support & $9.5(5.3-13.8)$ \\
\hline Education & $6.1(3.3-9.0)$ & $-\pi$ & - \\
\hline \multicolumn{4}{|l|}{ Louisiana } \\
\hline Health care and social assistance & $10.8(5.1-16.4)$ & - & 一 \\
\hline \multicolumn{4}{|l|}{ Maryland } \\
\hline Other services (except public administration) & $14.8(7.5-22.1)$ & Arts, design, entertainment, sports and media & $14.6(6.1-23.2)$ \\
\hline Health care and social assistance & $10.4(7.2-13.6)$ & Community and social services & $13.7(5.9-21.5)$ \\
\hline Education & $9.4(6.3-12.4)$ & Office and administrative support & $10.8(7.1-14.6)$ \\
\hline Public administration & $9.2(6.7-11.6)$ & Education, training, and library & $10.0(6.2-13.7)$ \\
\hline Professional, scientific, and technical services & $8.1(4.5-11.8)$ & Health care and technical & $9.4(5.7-13.1)$ \\
\hline \multicolumn{4}{|l|}{ Massachusetts } \\
\hline Information & $18.0(7.7-28.3)$ & Community and social services & $13.8(7.2-20.5)$ \\
\hline Accommodation and food services & $14.5(7.9-21.2)$ & Education, training, and library & $12.8(8.8-16.9)$ \\
\hline Public administration & $13.5(7.0-20.0)$ & Food preparation and service & $12.8(5.6-19.9)$ \\
\hline Health care and social assistance & $13.1(10.1-16.1)$ & Health care practitioners and technical & $12.4(8.8-16.1)$ \\
\hline Retail trade & $10.7(6.5-14.8)$ & Office and administrative support & $11.8(8.3-15.4)$ \\
\hline \multicolumn{4}{|l|}{ Michigan } \\
\hline Health care and social assistance & $15.2(12.1-18.3)$ & Health care support & $21.5(12.8-30.2)$ \\
\hline Accommodation and food services & $14.9(9.4-20.4)$ & Food preparation and service & $14.4(8.4-20.5)$ \\
\hline Education & $11.5(8.5-14.4)$ & Community and social services & $13.4(7.8-19.0)$ \\
\hline Retail trade & $11.4(7.7-15.0)$ & Sales and related & $12.4(8.3-16.4)$ \\
\hline Transportation and warehouse & $10.9(5.2-16.7)$ & Personal care and service & $12.3(6.8-17.9)$ \\
\hline \multicolumn{4}{|l|}{ Minnesota } \\
\hline Finance and insurance & $13.2(6.1-20.3)$ & Personal care and service & $13.4(6.1-20.7)$ \\
\hline Accommodation and food services & $12.9(6.3-19.5)$ & Health care practitioners and technical & $10.1(5.9-14.3)$ \\
\hline Health care and social assistance & $10.3(7.5-13.0)$ & Sales and related & $9.3(4.9-13.7)$ \\
\hline Manufacturing & $7.5(4.4-10.7)$ & Business and financial operations & $8.5(4.0-13.1)$ \\
\hline Retail trade & $6.4(3.5-9.4)$ & Office and administrative support & $6.5(3.7-9.2)$ \\
\hline \multicolumn{4}{|l|}{ Mississippi } \\
\hline Health care and social assistance & $7.5(4.3-10.7)$ & Health care practitioners and technical & $6.8(2.8-10.9)$ \\
\hline Retail trade & $6.1(2.7-9.4)$ & - & - \\
\hline Education & $4.3(1.9-6.7)$ & - & - \\
\hline \multicolumn{4}{|l|}{ Montana } \\
\hline Accommodation and food services & $9.4(5.0-13.9)$ & Office and administrative support & $8.0(4.8-11.3)$ \\
\hline Retail trade & $8.3(5.3-11.4)$ & Management & $7.9(5.0-10.8)$ \\
\hline Health care and social assistance & $8.1(5.4-10.7)$ & Health care practitioners and technical & $7.7(4.0-11.4)$ \\
\hline Construction & $7.9(4.2-11.6)$ & Construction and extraction & $7.6(4.0-11.1)$ \\
\hline Education & $7.8(4.7-11.0)$ & Sales and related & $7.3(4.0-10.7)$ \\
\hline \multicolumn{4}{|l|}{ Nebraska } \\
\hline Retail trade & $7.5(3.3-11.8)$ & Sales and related & $9.5(4.2-14.7)$ \\
\hline Education & $6.5(3.6-9.3)$ & Office and administrative support & $7.6(4.2-11.1)$ \\
\hline Health care and social assistance & $6.2(4.0-8.4)$ & Health care practitioners and technical & $6.7(3.0-10.4)$ \\
\hline Public administration & $5.7(2.5-9.0)$ & Management & $3.9(2.0-5.8)$ \\
\hline Agriculture, forestry, fishing, and hunting & $5.0(2.4-7.6)$ & (1) & - \\
\hline
\end{tabular}

See table footnotes on the next page. 
TABLE 3. (Continued) The five industries and occupations with the highest prevalence of current asthma* among adults employed in the 12 months preceding the interview, ${ }^{\dagger}$ by state - Behavioral Risk Factor Surveillance System (BRFSS), 21 states, 2013

\begin{tabular}{|c|c|c|c|}
\hline State/Industry & $\%^{\S}(95 \% \mathrm{Cl})$ & Occupation & $\%^{\S}(95 \% \mathrm{Cl})$ \\
\hline \multicolumn{4}{|l|}{ New Hampshire } \\
\hline Public administration & $12.3(5.7-18.9)$ & Office and administrative support & $12.3(7.1-17.4)$ \\
\hline Health care and social assistance & $9.9(7.0-12.8)$ & Sales and related & $11.7(7.0-16.5)$ \\
\hline Manufacturing & $9.2(5.5-12.9)$ & Computer and mathematical & $11.4(5.0-17.8)$ \\
\hline Retail trade & $8.7(4.7-12.6)$ & Health care practitioners and technical & $10.8(6.0-15.6)$ \\
\hline Other services (except public administration) & $8.1(3.9-12.3)$ & Education, training, and library & $7.6(4.1-11.1)$ \\
\hline \multicolumn{4}{|l|}{ New Jersey } \\
\hline Education & $9.5(5.3-13.7)$ & Education, training, and library & $8.9(3.9-13.9)$ \\
\hline Health care and social assistance & $9.0(4.7-13.3)$ & Health care practitioners and technical & $8.5(3.6-13.4)$ \\
\hline Retail trade & $7.7(3.2-12.2)$ & Management & $7.5(3.4-11.7)$ \\
\hline \multicolumn{4}{|l|}{ New Mexico } \\
\hline Education & $11.2(7.3-15.2)$ & Personal care and service & $12.7(6.6-18.8)$ \\
\hline Public administration & $10.6(5.6-15.6)$ & Health care practitioners and technical & $11.7(6.3-17.1)$ \\
\hline Retail trade & $9.5(5.2-13.8)$ & Education, training, and library & $11.3(6.2-16.3)$ \\
\hline Other services (except public administration) & $9.4(4.1-14.7)$ & Sales and related & $11.1(6.5-15.6)$ \\
\hline Health care and social assistance & $8.9(6.2-11.7)$ & Office and administrative support & $9.3(5.6-13.0)$ \\
\hline \multicolumn{4}{|l|}{ New York } \\
\hline Health care and social assistance & $9.5(6.1-12.8)$ & Office and administrative support & $10.3(4.2-16.3)$ \\
\hline Education & $8.1(4.3-12.0)$ & Management & $9.8(4.2-15.5)$ \\
\hline \multicolumn{4}{|l|}{ North Dakota } \\
\hline Manufacturing & $11.2(5.6-16.7)$ & Office and administrative support & $11.2(6.9-15.5)$ \\
\hline Health care and social assistance & $9.2(6.0-12.4)$ & Health care practitioners and technical & $8.8(4.2-13.5)$ \\
\hline Mining, oil, and gas & $8.8(4.2-13.5)$ & Construction and extraction & $8.1(3.4-12.7)$ \\
\hline Construction & $7.6(3.2-11.9)$ & Education, training, and library & $7.6(3.9-11.3)$ \\
\hline Retail trade & $6.4(3.5-9.3)$ & Sales and related & $5.9(3.2-8.5)$ \\
\hline \multicolumn{4}{|l|}{ Oregon } \\
\hline Public administration & $16.7(9.1-24.2)$ & Sales and related & $14.7(6.7-22.8)$ \\
\hline Health care and social assistance & $14.0(9.8-18.1)$ & Office and administrative support & $12.5(7.6-17.4)$ \\
\hline Manufacturing & $9.9(5.6-14.2)$ & Health care practitioners and technical & $10.9(5.9-15.8)$ \\
\hline Education & $8.9(5.0-12.9)$ & Education, training, and library & $8.7(4.0-13.4)$ \\
\hline \multicolumn{4}{|l|}{ Utah } \\
\hline Mining, oil, and gas & $13.5(5.8-21.2)$ & Personal care and service & $14.0(7.3-20.7)$ \\
\hline Other services (except public administration) & $12.4(7.4-17.4)$ & Production & $12.9(8.1-17.8)$ \\
\hline Manufacturing & $10.4(7.3-13.6)$ & Transportation and material moving & $10.9(5.9-15.9)$ \\
\hline Transportation and warehouse & $10.1(5.3-15.0)$ & Education, training, and library & $10.1(6.8-13.4)$ \\
\hline Professional, scientific, and technical services & $9.9(5.9-13.9)$ & Office and administrative support & $9.2(6.7-11.6)$ \\
\hline \multicolumn{4}{|l|}{ Washington } \\
\hline Accommodation and food services & $16.1(9.0-23.1)$ & Personal care and service & $17.4(9.6-25.2)$ \\
\hline Retail trade & $12.5(8.6-16.4)$ & Food preparation and service & $16.1(8.3-23.8)$ \\
\hline Health care and social assistance & $12.5(9.4-15.6)$ & Building and grounds cleaning and maintenance & $14.2(6.6-21.8)$ \\
\hline Administrative, support, waste management, and remediation & $11.5(5.6-17.4)$ & Health care practitioners and technical & $11.8(7.4-16.1)$ \\
\hline Professional, scientific, and technical services & $9.4(6.3-12.4)$ & Sales and related & $11.6(7.0-16.2)$ \\
\hline \multicolumn{4}{|l|}{ Wisconsin } \\
\hline Health care and social assistance & $11.4(6.8-15.9)$ & Office and administrative support & $9.6(5.1-14.1)$ \\
\hline Manufacturing & $8.1(4.8-11.5)$ & Sales and related & $7.8(3.3-12.2)$ \\
\hline Retail trade & $7.5(3.8-11.2)$ & - & - \\
\hline Education & $7.3(3.3-11.3)$ & - & - \\
\hline \multicolumn{4}{|l|}{ Wyoming } \\
\hline Accommodation and food services & $15.0(7.3-22.6)$ & Production & $14.1(6.1-22.2)$ \\
\hline Education & $10.9(6.7-15.1)$ & Education, training, and library & $12.5(7.1-17.8)$ \\
\hline Health care and social assistance & $10.4(6.2-14.6)$ & Sales and related & $9.7(4.2-15.2)$ \\
\hline Mining, oil, and gas & $7.6(3.6-11.6)$ & Office and administrative support & $8.4(4.3-12.5)$ \\
\hline Retail trade & $7.4(3.1-11.7)$ & Health care practitioners and technical & $8.1(3.4-12.9)$ \\
\hline
\end{tabular}

Abbreviation: $\mathrm{Cl}=$ confidence interval.

* "Yes" response to both questions: "Have you ever been told by a doctor or other health professional that you have asthma?" and "Do you still have asthma?"

† Participants who, at the time of the interview, indicated they were employed for wages, out of work for $<1$ year, or self-employed.

$\S$ Weighted to the state population using the survey sample weights for each BRFSS participant.

n Unreliable estimates with a relative standard error $\geq 30$ are not reported. 


\section{Discussion}

The findings in this report provide the first state-specific estimates of current asthma by industry and occupation category for 21 states administering BRFSS and collecting industry and occupation data, and indicate state-specific variations in current asthma prevalence by industry and occupation. These variations are consistent with previous findings (3) and likely reflect differences in the characteristics of state working populations (e.g., age, race/ethnicity, and education), socioeconomic factors (e.g., state-specific distribution of industries and occupations and unemployment rate), health insurance coverage (e.g., type of insurance and access to medical care), state laws (e.g., workers' compensation), geographic differences in prevalence of sensitization to aeroallergens $(4,5)$, and risk for exposure to agents causing asthma in the workplace. For example, sales and related occupations were the top employers in 2015 for all 21 states assessed in this study according to the Bureau of Labor and Statistics (http://www.bls.gov/home.htm) and that might explain why this occupation appears consistently across several states.

Work-related asthma includes occupational asthma (i.e., new-onset asthma caused by factors related to work) and work-exacerbated asthma (i.e., preexisting or current asthma worsened by factors related to work) (1). Persons with workrelated asthma have more symptomatic days, use more health care resources, and have lower quality of life (G). Moreover, asthma exacerbations accelerate decline in lung function (7). Each of the industries and occupations identified in this report is associated with a specific set of existing and emerging workplace exposures, including irritant chemicals, dusts, secondhand smoke, allergens, emotional stress, temperature, and physical exertion, that have been associated with new-onset and work-exacerbated asthma $(8,9)$. For example, it is well recognized that workers in the health care and social assistance industry who are exposed to cleaning and disinfection products, powdered latex gloves, and aerosolized medications have a twofold increased likelihood of new-onset asthma (9). A previous study reported that as much as $48 \%$ of adult asthma is caused or made worse by work (2); therefore, as many as 2.7 million workers might have asthma caused or exacerbated by workplace conditions in these 21 states. To assist clinicians in assessing potential workplace exposures among employed patients with new-onset or exacerbated asthma, the Association of Occupational and Environmental Clinics published a list of substances that meet criteria for causing work-related asthma by sensitization or acute irritant-induced asthma.99

\footnotetext{
99 http://www.aoecdata.org/ExpCodeLookup.aspx.
}

\section{Summary}

What is already known about this topic?

Data from the 2006-2007 adult Behavioral Risk Factor Surveillance System (BRFSS) Asthma Call-back Survey from 33 states indicated that up to $48 \%$ of adult current asthma might be related to work and could potentially be prevented. Asthma prevalence is higher among adults working in certain industries and occupations.

What is added by this report?

Among an estimated 74 million adults employed at some time in the 12 months preceding the interview in 21 states, $7.7 \%$ had current asthma (range $=5.0 \%$ [Mississippi]-10.0\% [Michigan]). Based on the Asthma Call-back Survey results, this finding means as many as 2.7 million U.S. workers might have asthma caused by or exacerbated by workplace conditions. The findings indicate state-specific variation in the prevalence of current asthma by industry and occupation. State-specific prevalence of current asthma was highest among workers in the information industry (18.0\%) in Massachusetts and in health care support occupations (21.5\%) in Michigan.

What are the implications for public health practice?

Analysis of BRFSS industry and occupation and asthma module data might aid in identification of industries and occupations with high current asthma prevalence and facilitate assessment of workers for new-onset or work-exacerbated asthma who could benefit from work-related asthma prevention and education programs. Routine collection of industry and occupation information is needed to estimate state-specific work-related asthma prevalence by industry and occupation.

The findings in this report are subject to at least four limitations. First, information on asthma was self-reported and not validated by medical records or follow-up with health care providers; thus, estimates might be subject to misclassification. Second, although the BRFSS optional ACBS collects detailed information on asthma (e.g., work-related asthma), it was not possible to determine whether the current asthma was associated with work using 1 year of data because of the small number of respondents with both information on workrelated asthma diagnosis and industry and occupation. Also, small sample sizes resulted in unreliable estimates for some industries and occupations. Combining multiple years of data from ACBS and industry and occupation module is needed to estimate the state-specific work-related asthma prevalence by industry and occupation. Third, workers with current asthma might leave employment in industries and occupations with workplace exposures that exacerbate their asthma (i.e., the healthy worker effect); thus, industry and occupation in this report might not accurately represent the industries and occupations where exposures occur. Finally, because data are limited 
to 21 states, the results might not be nationally representative or representative of nonparticipating states.

Physicians should consider collecting a detailed occupational history among adults with asthma because this is critical for making a work-related asthma diagnosis and recommending optimal treatment and management (1). Reduction or elimination of workplace exposures (i.e., substitution of hazardous products with nonhazardous products or improved ventilation) or removal of the worker from the environment might be necessary for management of asthma symptoms related to work $(1,10)$. For example, reduction in exposure to latex allergens by replacing powdered latex gloves with powder-free natural rubber latex or nonlatex gloves considerably reduced work-related asthma in the health care industry $(10)$.

Twenty-two Healthy People 2020 respiratory disease objectives $^{* * *}$ for asthma address prevention, detection, treatment, and education efforts; in 2009, CDC funded 34 states, the District of Columbia, and Puerto Rico to help meet these objectives. ${ }^{\dagger \dagger}$ The Council of State and Territorial Epidemiologists in its 2010 Position Statement $\$ \$ \$ \$ \$$ recommends continued surveillance for and evaluation of the burden of asthma, including work-related asthma, to help target prevention programs and activities. BRFSS data provide a unique opportunity to assess state-level asthma prevalence by industry and occupation. The findings in this report might assist physicians and state public health officials in identifying workers in industries and occupations with a high current asthma prevalence who should be evaluated for work-related asthma in order to plan and target interventions. Potential work-related asthma exposures can be identified, and effective prevention and education strategies can be implemented (8). Routine collection of industry and occupation information is needed to estimate state-specific work-related asthma prevalence by respondents' industry and occupation.

\footnotetext{
*** https://www.healthypeople.gov/2020/topics-objectives/topic/respiratorydiseases/objectives.

${ }^{\dagger \dagger \dagger}$ http://www.cdc.gov/asthma/pdfs/asthma_facts_program_grantees.pdf.

$\$ S \$$ http://c.ymcdn.com/sites/www.cste.org/resource/resmgr/PS/10-EH-01.pdf.
}

\section{Acknowledgments}

BRFSS state coordinators; Naomi Anderson, MPH, Washington Department of Labor and Industries; Jennifer Marcum, DrPH, Washington Department of Labor and Industries; Karla Armenti, $\mathrm{ScD}$, University of New Hampshire.

${ }^{1}$ Respiratory Health Division, National Institute for Occupational Safety and Health, CDC; ${ }^{2}$ Association of Schools and Programs of Public Health/CDC Public Health Fellowship Program.

Corresponding author: Katelynn Dodd, yla8@cdc.gov, 304-285-6305.

\section{References}

1. Tarlo SM, Balmes J, Balkissoon R, et al. Diagnosis and management of work-related asthma: American College Of Chest Physicians consensus statement. Chest 2008;134(Suppl):1S-41S. http://dx.doi.org/10.1378/ chest.08-0201

2. Knoeller GE, Mazurek JM, Moorman JE. Work-related asthma among adults with current asthma in 33 states and DC: evidence from the Asthma Call-Back Survey, 2006-2007. Public Health Rep 2011;126:603-11.

3. Anderson NJ, Fan ZJ, Reeb-Whitaker C, Bonauto DK, Rauser E. Distribution of asthma by occupation: Washington State Behavioral Risk Factor Surveillance System data, 2006-2009. J Asthma 2014;51:1035-42. http://dx.doi.org/10.3109/02770903.2014.939282

4. Xu F, Mawokomatanda T, Flegel D, et al. Surveillance for certain health behaviors among states and selected local areas-Behavioral Risk Factor Surveillance System, United States, 2011. MMWR Surveill Summ 2014;63(No. SS-9).

5. Salo PM, Arbes SJ Jr, Jaramillo R, et al. Prevalence of allergic sensitization in the United States: results from the National Health and Nutrition Examination Survey (NHANES) 2005-2006. J Allergy Clin Immunol 2014;134:350-9. http://dx.doi.org/10.1016/j.jaci.2013.12.1071

6. Balmes J, Becklake M, Blanc P, et al. American Thoracic Society statement: occupational contribution to the burden of airway disease. Am J Respir Crit Care Med 2003;167:787-97. http://dx.doi.org/10.1164/rccm.167.5.787

7. O’Byrne PM, Pedersen S, Lamm CJ, Tan WC, Busse WW; START Investigators Group. Severe exacerbations and decline in lung function in asthma. Am J Respir Crit Care Med 2009;179:19-24. http://dx.doi. org/10.1164/rccm.200807-1126OC

8. Henneberger PK, Redlich CA, Callahan DB, et al.; ATS Ad Hoc Committee on Work-Exacerbated Asthma. An official American Thoracic Society statement: work-exacerbated asthma. Am J Respir Crit Care Med 2011;184:368-78. http://dx.doi.org/10.1164/rccm.812011ST

9. Pechter E, Davis LK, Tumpowsky C, et al. Work-related asthma among health care workers: surveillance data from California, Massachusetts, Michigan, and New Jersey, 1993-1997. Am J Ind Med 2005;47:265-75. http://dx.doi.org/10.1002/ajim.20138

10. Heederik D, Henneberger PK, Redlich CA; ERS Task Force on the Management of Work-related Asthma. Primary prevention: exposure reduction, skin exposure and respiratory protection. Eur Respir Rev 2012;21:112-24. http://dx.doi.org/10.1183/09059180.00005111 